Pesq. Vet. Bras. 29(4):295-302, abril 2009

\title{
Effects of ascorbic acid supplementation in ileum myenteric neurons of streptozotocin-induced diabetic rats ${ }^{1}$
}

\author{
Sonia M. Silverio ${ }^{2}$, Renata de B. Mari ${ }^{*}$, Naianne K. Clebis ${ }^{4}$, Juliana R. Scoz ${ }^{2}$, \\ Ricardo de M. Germano ${ }^{2}$, José A.A. Major ${ }^{2}$, Pedro P. Bombonato ${ }^{3}$ and \\ Sandra R. Stabille ${ }^{2}$
}

\begin{abstract}
Silverio S.M., Mari R.B, Clebis N.K., Scoz J.R., Germano R.M., Major J.A.A., Bombonato P.P. \& Stabille S.R. 2009. Effects of ascorbic acid supplementation in ileum myenteric neurons of streptozotocin-induced diabetic rats. Pesquisa Veterinária Brasileira 29(4):295-302. Departamento de Cirurgia, Setor de Anatomia dos Animais Domésticos e Silvestres, Faculdade de Medicina Veterinária e Zootecnia, Universidade de São Paulo, Av. Prof. Dr. Orlando Marques de Paiva 87, São Paulo, SP 05508-270, Brazil. E-mail: remari@usp.br

The exacerbation of the oxidative stress and of the polyol pathway which impair damage myenteric plexus are metabolic characteristics of diabetes. The ascorbic acid (AA) is an antioxidant and an aldose reductase inhibitor, which may act as neuroprotector. The effects of AA supplementation on the density and cellular body profile area (CP) of myenteric neurons in STZ-induced diabetes in rats were assessed. Four groups with five animals each were formed: normoglycemic (C); diabetic (D); AA-treated diabetic (DS) and AA-treated normoglycemic (CS). Dosagen of $50 \mathrm{mg}$ of AA were given, three times a week, for each animal (group DS and CS). Ninety days later and after euthanasia, the ileum was collected and processed for the NADPH-diaphorase technique. There were no differences $(P>0.05)$ in the neuronal density among the groups. The CP area was lower $(P<0.05)$ in the DS and CS groups, with a higher incidence of neurons with a CP area exceeding $200 \mu \mathrm{m}^{2}$ for groups $C$ and $D$. The AA had no influence on the neuronal density in the ileum but had a neuroprotective effect, preventing the increase in the CP area and allowing a higher number of neurons with a CP area with less than $200 \mu \mathrm{m}^{2}$.
\end{abstract}

INDEX TERMS: Vitamin C, diabetes, intestine, myenteric plexus.

RESUMO.- [Efeitos da suplementação do ácido ascórbico nos neurônios mientéricos do íleo de ratos diabéticos induzidos por estreptozootocina.] A exacerbação do estresse oxidativo e da via do poliol que comprometem o plexo mioentérico são alterações metabólicas características do diabetes. O ácido ascórbico (AA) é

\footnotetext{
${ }^{1}$ Received on May 21, 2008.

Accepted for publication on January 7, 2009.

2 Instituto de Ciências Biológicas, Médicas e de Saúde, Universidade Paranaense (Unipar), Av. Huberto Brüning 360, Jardim Santos Dumont, Paranavaí, PR 87706-490, Brazil. *Corresponding author: remari@usp.br

${ }^{3}$ Departamento de Cirurgia, Faculdade de Medicina Veterinária e Zootecnia (FMVZ), Universidade de São Paulo (USP), Av. Prof. Dr. Orlando Marques de Paiva 87, São Paulo, SP 05508-270, Brazil.

${ }^{4}$ Departamento de Morfologia, Centro de Ciências Biomédicas, Universidade Federal do Rio Grande do Norte, Cx. Postal 1524, Campus Universitário Lagoa Nova, Natal, RN 59072-970, Brazil.
}

antioxidante e inibidor da aldose redutase, podendo atuar como neuroprotetor. Verificaram-se os efeitos da suplementação com AA sobre o número e a área do perfil do corpo celular $(\mathrm{PC})$ de neurônios mioentéricos em ratos diabéticos induzidos por estreptozootocina. Formaram-se quatro grupos com cinco animais cada: normoglicêmico (C); diabético (D); diabético tratado com AA (DS); e normoglicêmico tratado com AA (CS). Três vezes por semana administrou-se $50 \mathrm{mg}$ de AA para cada animal (grupos DS e CS). Após 90 dias e eutanásia com tiopental, o íleo foi coletado e processado para a técnica da NADPHdiaforase. Não se observaram diferenças $(P>0,05)$ na densidade neuronal entre os grupos. $A$ área do $P C$ foi menor $(P<0,05)$ para os grupos DS e CS, com incidência maior de neurônios com área do PC superior a $200 \mu \mathrm{m}^{2}$ para os grupos C e D. Concluiu-se que o AA não influenciou a densidade neuronal do íleo, mas foi neuroprotetor 
prevenindo o aumento na área do $\mathrm{PC}$ e possibilitando maior incidência de neurônios com área de PC inferior a $200 \mu \mathrm{m}^{2}$.

TERMOS DE INDEXAÇÃO: Vitamina C, diabetes, intestino, plexo mientérico.

\section{INTRODUCTION}

The normal functioning of the digestive tube depends highly on the integrity of neurons in the enteric nervous system whose neurochemical diversity exceeds that of the peripheral nervous system (Brehmer et al. 2004). The myenteric and submucosal plexus of the enteric nervous system work mainly in the motility coordination and control as well as the secretion and absorption processes occurring in the gastrointestinal segments (Bornstein et al. 2004).

In higher vertebrates, the myenteric plexus is located between the longitudinal and circular strata of the muscle layer of the gastrointestinal segments forming a neuron network gathered predominantly in ganglia interconnected by bundles of nerve fibers (Gabella 1979, 1990, Molinari et al. 1994, Sant'Ana et al. 1997, Furness 2000, Mari et al. 2007, Silva et al. 2008).

Changes in neurons of the myenteric plexus have been described in different conditions and experimental models which have tried to elucidate the mechanisms that lead to functional impairment of the digestive tube (Fregonesi et al. 2001, Sant'Ana et al. 2001, Furlan et al. 2002, Molinari et al. 2002, Zanoni et al. 2003, Fontes et al. 2004, Alves et al. 2006, Araújo et al. 2006, Silverio et al. 2008, Silva et al. 2008).

Diabetes mellitus (DM) is a syndrome of multiple etiologies characterized by chronic hyperglycemia with changes in the metabolism of carbohydrates, lipids and proteins leading to, among other complications, peripheral and autonomic neuropathies. Among the consequences of the diabetic neuropathy there are reports of stomach hypotonia and dilation with a slow gastric emptying (Block et al. 2002), intestinal involvement with episodes of diarrhea with night exacerbation followed by fecal incontinence alternating with episodes of constipation (Watkins et al. 2000). In part, the gastrointestinal disorders associated with $\mathrm{DM}$ are correlated to changes in the quantity and size of myenteric neurons (Diane et al. 1979).

There are sub-populations of myenteric neurons that respond differently to DM. Some neurons degenerate, others suffer changes in their neurotransmitters without undergoing degeneration, while others are not affected (Chandrasekharan \& Srinivasan 2007). Similarly, the neurons containing the same types of neurotransmitters, but innervate different regions of the digestive tube, are affected differently in DM.

The nitrergic neurons are among the neurons that have been extensively studied within the Enteric Nervous System. Nitric oxide (NO) is produced by nitric oxide synthase during the transformation of L-arginine into L- citrulline. Once formed, the NO takes part in the relaxation or inhibition of the smooth muscle contraction, thus, acting in the regulation of gastrointestinal motility (Kurjak et al. 2001).

The relationship between hyperglycemia and diabetic neuropathy has already been demonstrated in several studies and, among the theories proposed to its etiology, the oxidative stress stands out (Giuliano et al. 1996, Afzaal et al. 2002). The oxidative stress occurs when there is an imbalance between the production of oxidants and the body's defense system leading to the increase of molecules reactive to oxygen (free radicals) within the cells (Parthiban et al. 1995, Obrosova et al. 2002). Biological systems have non-enzymatic and enzymatic mechanisms which form the first line of defense against the reactive oxygen species (Rigo \& Guterres 2002). In the diabetes neuropathy and some other complications, the oxidative stress is intensified by the reduction in the levels of enzymes participating in the antioxidant defense system (Parthiban et al. 1995, Obrosova et al. 2002) as well as by the reduction in the antioxidants levels such as ascorbic acid (AA), glutathione and vitamin E (Young et al. 1992, Lee \& Chung 1999).

The NOS enzyme stains neurons through the reduction of nitro-blue tetrazolium in the presence of beta-nicotinamide adenine dinucleotide phosphate reduced (NADPHreduced), indicating that the nadph-diaphorase histochemistry can be used as a NO marker (Santer 1994).

Quantitative changes in the nitrergic neurons from the myenteric plexus and a reduction in the expression and activity of NOS have been reported in diabetic animals (Wrzos et al. 1997, Spangéus et al. 2000, Watkins et al. 2000, Surendran \& Kondapaka 2005), reinforcing the findings of the impairment of the myenteric plexus in diabetic autonomic neuropathy.

Multiple therapeutic strategies have shown that the treatment with antioxidants may prevent or reverse peripheral nerve dysfunction in STZ-induced diabetic rats (Cameron et al. 1993, Cameron \& Cotter 1999). The AA supplementation reduces the capillary fragility and the sorbitol cellular concentration (Cunningham 1998), which suggests a neuroprotective role for this substance. Therefore, the aim of this research... was to observe possible effects of AA-treatment in NADPH-diaphorase myenteric neurons present in the ileum of chronic STZinduced diabetic rats through quantitative and morphometric analysis.

\section{MATERIALS AND METHODS}

This study was done within the guidelines of the COBEA (Brazilian College for Animal Experimentation) and was approved by the CEPEEA (Institutional Committee for Ethics in Animal Experimentation) from Unipar.

Twenty male rats (Rattus norvegicus) of Wistar lineage with 3 months of age, supplied by the Central Vivarium of the University of São Paulo, were used. The animals were distributed in four groups with five animals each $(n=5)$ as follows: Group D (STZ-induced diabetic); Group C (normoglycemic control); Group 
DS (STZ-induced diabetic AA-treated), and Group CS (AAtreated normoglycemic control).

The animals were housed in separate polypropylene cages, at room temperature $\left(24 \pm 2^{\circ} \mathrm{C}\right)$ and controlled photoperiod $(12$ hours dark/light cycle) with access to food and water ad libitum. During the 90-days experiment period, the animals were weighed once a week.

\section{Streptozotocin-induced diabetes and ascorbic acid supplementation (AA)}

After 14 hours fasting, each animal of groups D and DS received a single dose of streptozotocin $(35 \mathrm{mg} / \mathrm{kg}$ of body weight) dissolved in sodium citrate buffer $10 \mathrm{~mm}, \mathrm{pH} 4.5$, through intravenous injection. The animals from Group $\mathrm{C}$ and CS received the same dose of $10 \mathrm{~mm}$ sodium citrate buffer. One week after the induction and confirmation of diabetes onset (blood glucose exams), every animal from Group CS and DS received $50 \mathrm{mg}$ of AA (through gavage), three times a week, during 90 days.

\section{Obtaining intestinal segments}

At the end of the experimental period, after fasting for 12 hours, the animals were euthanatized with a lethal dose of anaesthetic (Thiopental Abbout ${ }^{\circledR} 40 \mathrm{mg} / \mathrm{kg}$ ) given by intravenous injection. Blood was collected through cardiac punction in order to measure the glucose levels. A laparotomy was then carried out to retrieve the ileum.

\section{NADPH-diaphorase histochemical technique (Scherer- Singler et al. 1983) \\ The collected ileum was washed and filled with phosphate} buffer (PB pH 7.4), and after had their extremities tied with suture thread, were fixed in $4 \%$ paraformaldehyde (Merk, Darmstad, Germany) prepared in $0.1 \mathrm{M}$ phosphate buffer (PB; $\mathrm{pH}$ 7.4) for 30 minutes, immersed in $0.3 \%$ Triton X-100 (Sigma, St. Louis, USA) dissolved in phosphate-buffered saline (PBS, pH 7.4) for 10 minutes and then washed ten times (10 minutes each) in PBS. Subsequently, ileum was incubated in a broth containing $50 \mathrm{mg}$ of Nitro Blue Tetrazolium (Sigma®), $50 \mathrm{mg}$ of b-NADPH $\left(\right.$ Sigma $\left.{ }^{\circledR}\right)$ and $0.3 \%$ Triton $\mathrm{X}-100$ in buffered Tris- $\mathrm{HCl}$ drain plug (0.1M pH 6.0).

The histochemical reaction was controlled visually with the aid of stereomicroscope and lasted for 100 minutes. Then, the ileum was opened by cutting to sutures at their extremities, washed three times in PBS for 5 minutes and then immersed in $4 \%$ paraformaldehyde solution for setting and storage.

\section{Obtaining the membrane whole-mounts}

The ileum was sectioned throughout the extension of the mesenteric edge and microdissected in a glass plate under the stereomicroscope with transillumination to remove the mucosal and e submucosal layers, preserving the muscular and serosal layers. Each membrane whole-mount was dehydrated in an ascending series of alcohols (90-100\%) and clarified by three consecutive immersions in xylol, then placed between glass blade with Permount ${ }^{\circledR}$ resin. The membrane whole-mount preparations were used for the quantification and morphometric analyses of the cellular body profile area of myenteric neurons.

\section{Quantification of NADPH-diaphorase positive neurons \\ The ileum membrane whole-mount was visualized by light microscope in order to perform the neuronal quantification area}

$\left(\mathrm{mm}^{2}\right)$. The image seen in the microscope was captured by a high resolution digital camera and transferred to a computer.

The neurons were quantified by means of a system test adapted to each membrane whole-mount consisting of 60 fields. Based on the width and length of the membrane whole-mount preparations, the 60 fields were distributed as ten columns with six lines each, sampling all regions (mesenteric, intermediate and anti-mesenteric).

\section{Measurement of the cell body profile (CP) area of NADPH- diaphorase positive neurons}

The measurement of the CP area of NADPH-diaphorase positive (NADPH-dp) myenteric neurons was carried through image-analyses software (Image-Pro-Plus 3.0.1). The images of the neurons captured for digital chamber for the quantification of the neuronal density had been used. The CP (in ìm²) of all the neurons quantified previously in the membrane whole-mount preparations of each animal for group had been measured. The neurons had been grouped by class intervals of $100 \mathrm{im}^{2}$.

\section{Statistical analysis}

All the results were expressed as mean \pm standard error. The data from different groups were compared by the Tukey's test. The adopted significance level for all groups was $\mathrm{P}<0.05$.

\section{RESULTS}

The glucose blood concentration of animals in groups $D$ and DS were higher $(P<0.05)$ than those found for the animals in Group C and CS (Table 1). There were no differences $(P>0.05)$ in blood glucose between animals of Group D and DS (Table 1).

Throughout the trial period (90 days), the animals in all groups showed an increase in their body weight (Table 1). Weight gain was lower for animals in Group D and DS when compared to animals in Group C and CS, but the difference between them were not significant $(P>0.05)$.

The light microscopy analysis of the ileum membrane whole-mounts showed no changes in the myenteric plexus organization and arrangement among the groups. The

Table 1. Means and standard mean error of the blood glucose initial concentration (90 days old) and the end (180 days old) and body weight at the beginning (90 days old) and the end of the experiment ( 180 days old) of animals in groups $\mathbf{C}$ (control-normoglycemic), CS (control normoglycemic treated with ascorbic acid), D (STZinduced diabetes) and SD (STZ-induced diabetes and treated with ascorbic acid)

\begin{tabular}{ccc}
\hline Groups & Initial glucose $\left(\mathrm{mg} \mathrm{dL}^{-1}\right)$ & Final glucose $\left(\mathrm{mg} \mathrm{dL}^{-1}\right)$ \\
\hline C $(\mathrm{n}=5)$ & $101.3^{\mathrm{a}} \pm 5.26$ & $101.3^{\mathrm{a}} \pm 3.54$ \\
CS $(\mathrm{n}=5)$ & $97.25^{\mathrm{a}} \pm 4.73$ & $95^{\mathrm{a}} \pm 2.85$ \\
$\mathrm{D}(\mathrm{n}=5)$ & $387^{\mathrm{b}} \pm 16.97$ & $446.5^{\mathrm{b}} \pm 5.33$ \\
DS $(\mathrm{n}=5)$ & $395.5^{\mathrm{b}} \pm 4.62$ & $436.5^{\mathrm{b}} \pm 1.37$ \\
& Initial body weight $(\mathrm{g})$ & Final body weight $(\mathrm{g})$ \\
$\mathrm{C}(\mathrm{n}=5)$ & $295^{\mathrm{a}} \pm 15.81$ & $430.3^{\mathrm{b}} \pm 27.4$ \\
CS $(\mathrm{n}=5)$ & $301.5^{\mathrm{a}} \pm 2.05$ & $430.4^{\mathrm{b}} \pm 20.39$ \\
D $(\mathrm{n}=5)$ & $283.3^{\mathrm{a}} \pm 11.24$ & $395.5^{\mathrm{b}} \pm 312$ \\
DS $(\mathrm{n}=5)$ & $314^{\mathrm{a}} \pm 12.25$ & $367.5^{\mathrm{b}} \pm 59.25$ \\
\hline
\end{tabular}

Means followed by different letters in the same line and column are different $(P<0.05)$ by the Tukey's test. 

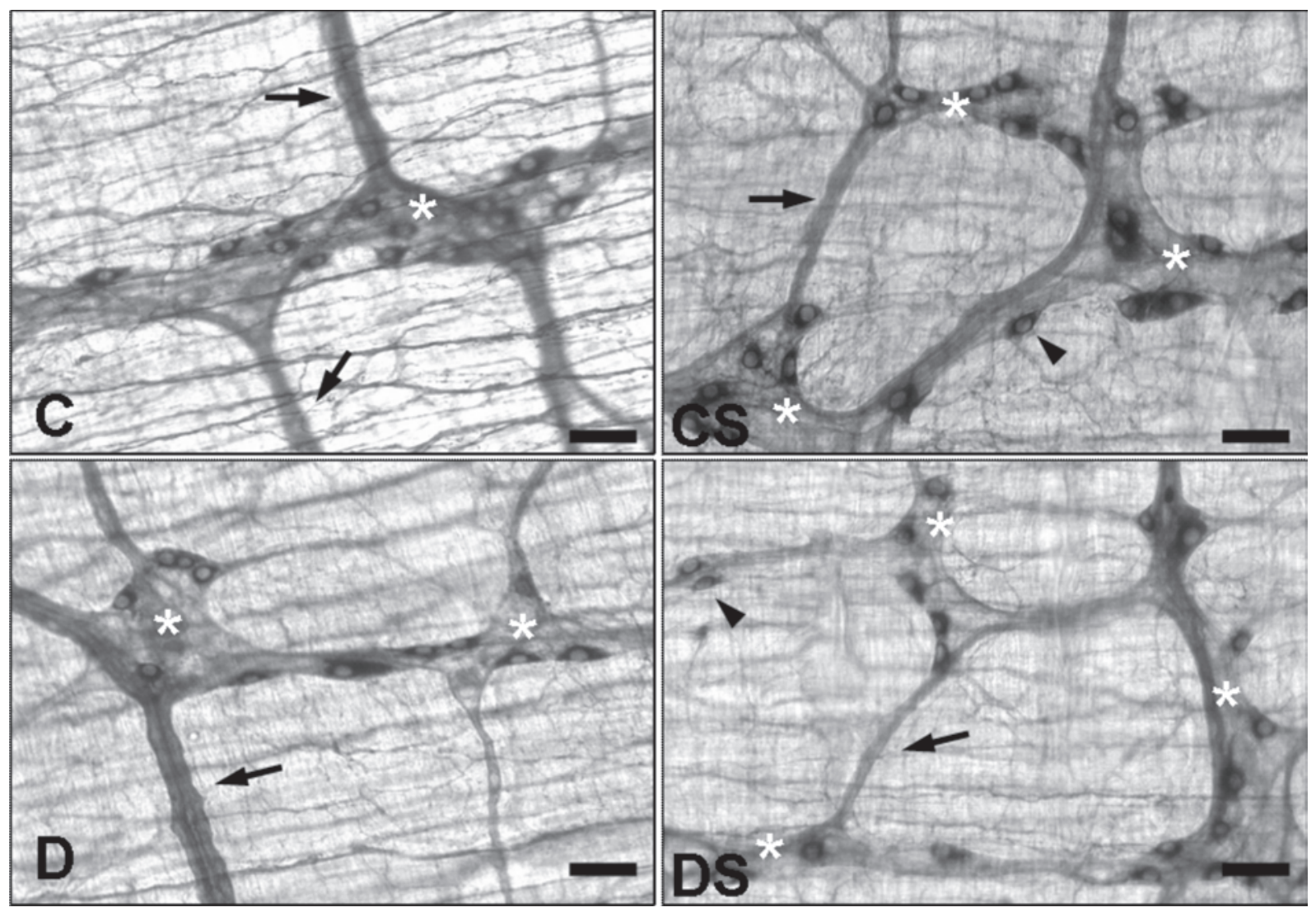

Fig.1. Photomicrography of ganglia in the ileum myenteric plexus showing NADPH-diaphorase positive neurons, in normoglycemic groups (C); STZ-induced diabetes (D); AA-treated STZ-induced diabetes (DS) and normoglycemic AA-treated (CS), respectively. (Bar: 10ìm). Observed neurons arranged predominantly within the ganglia $\left({ }^{*}\right)$ and interganglia fibers with different thicknesses (arrow) with isolated neurons, in the fibers path (head of arrow).

NADPH-dp myenteric neurons were gathered predominantly in ganglia interconnected by nerve fibers bundles (Fig.1A) and distributed homogeneously between the mesenteric, intermediate and antimesenteric regions of the ileum circumference. Isolated neurons, especially in the nerve fibers path, were also found (Fig.1B). Neurons inside the ganglia had a scattered arrangement, closer to the ganglia peripheral region (Fig.1C,D,E,F).

The density of NADPH-dp neurons present in 13.33 $\mathrm{mm}^{2}$ of ileum (area equivalent to 60 fields viewed under

Table 2. Means and standard error (SE) of: the NADPHdiaphorase stained neurons present in $13.33 \mathrm{~mm}^{2}$ of ileum whole-mount preparations and respective cellular profile area (CP) from animals in group $C$ (controlnormoglycemic), CS (AA-treated control normoglycemic), D (STZ-induced diabetes) and SD (STZ-induced diabetes and AA-treated)

\begin{tabular}{ccc}
\hline Groups & Neuron density/13.33mm & CP area $\left(\mu \mathrm{m}^{2}\right)$ \\
\hline C $(\mathrm{n}=5)$ & $97.8^{\mathrm{a}} \pm 4.54$ & $289.7^{\mathrm{a}} \pm 5.62$ \\
CS $(\mathrm{n}=5)$ & $100.8^{\mathrm{a}} \pm 5.4$ & $210.1^{\mathrm{b}} \pm 3.14$ \\
$D(\mathrm{n}=5)$ & $94.2^{\mathrm{a}} \pm 5.44$ & $289.8^{\mathrm{a}} \pm 5.5$ \\
DS $(\mathrm{n}=5)$ & $104.2^{\mathrm{a}} \pm 8.75$ & $253.1^{\mathrm{C}} \pm 4.22$ \\
\hline
\end{tabular}

Means followed by different letters in the same column are different $(P<0.05)$ by Tukey's test. light microscopy with a 40x lens) did not differ ( $P>0.05)$ among the studied groups (Table 2).

The neuron PC area ranged $73.1-761.50 \mathrm{im}^{2}$ in Group D, 64.49-837.31 $\mu \mathrm{m}^{2}$ in Group C, $87.09-641.81 \mu \mathrm{m}^{2}$ for Group DS, and 61.47-449.93 $\mu^{2}$ in Group CS.

The neuron PC mean area measured in groups $D$ $\left(289.8 \pm 5.5 \mu \mathrm{m}^{2}\right)$ and $C\left(289.7 \pm 5.62 \mu \mathrm{m}^{2}\right)$ were equivalent, but differed $(P<0.05)$ from the neurons $P C$ area in the ileum of groups DS $\left(253.1 \pm 4.22 \mu \mathrm{m}^{2}\right)$ and CS $\left(210.1 \pm 3.14 \mu \mathrm{m}^{2}\right)$ (Table 2). Treatment with AA reduced the neurons $\mathrm{PC}$ area

Table 3. Relative frequency of NADPH-diaphorase neurons positives of groups C (control-normoglycemic), D (STZ-induced diabetes), CS (control normoglycemic

AA-treated) and SD (STZ-induced diabetes and AAtreated) according to class intervals of cell body profile (PC) area $\left(\mathrm{im}^{2}\right)$

\begin{tabular}{ccccc}
\hline PC $\left(\mu \mathrm{m}^{2}\right)$ & \multicolumn{4}{c}{ Relative frequency of neurons $(\%)$} \\
\cline { 2 - 5 } & Group C $(\mathrm{n}=5)$ & Group D $(\mathrm{n}=5)$ & Group DS $(\mathrm{n}=5)$ & Group CS $(\mathrm{n}=5)$ \\
\hline$<100$ & 1 & 1 & 1 & 2 \\
$100-200$ & 23 & 18 & 30 & 50 \\
$200-300$ & 39 & 46 & 44 & 37 \\
$300-400$ & 21 & 20 & 17 & 9 \\
$400-500$ & 10 & 8 & 6 & 2 \\
$>500$ & 6 & 7 & 2 & 0 \\
Total & 100 & 100 & 100 & 100
\end{tabular}


of Group DS and CS, $12.7 \%$ and $27.5 \%$ when compared to Group C and D, respectively.

An increase in the number of neurons with a $P C$ area lower to less than $200 \mu \mathrm{m}^{2}$ in the AA-treated group $(41 \%$ for Group DS and 52\% for Group CS) was verified when compared to Group C (24\%) and D (19\%); Group C and D showed a relative frequency of neurons with a $P C$ area higher than $200 \mu \mathrm{m}^{2}$ (Table 3). Thus, the AAsupplementation for diabetic and non-diabetic animals changed the incidence of neurons with a PC area higher to $200 \mu \mathrm{m}^{2}(\mathrm{C}=76 \%$; $\mathrm{D}=81 \%, \mathrm{SD}=69 \%$ and $\mathrm{CS}=48 \%$ ).

\section{DISCUSSION}

The STZ is a substance that induces the experimental diabetes and has been used to assess the behavior of neurons in the enteric nervous system of several gastrointestinal segments (Young et al. 1992, Büttow et al. 1997, Wrzos et al. 1997, Zanoni et al. 2003, Clebis et al. 2004, Fregonesi et al. 2005). In order to be effective in the diabetogenic activity it should be given in doses higher than $25 \mathrm{mg} / \mathrm{kg}$ of body weight (Junod et al. 1969).

The initial and final hyperglycemias in animals from Group D and DS (Table 1) showed blood glucose levels higher $(P>0.05)$ than those in Group $C$ and CS, confirming that the animals that received the STZ $(35 \mathrm{mg} / \mathrm{kg})$ remained diabetic throughout the trial period (90 days).

Similar results of the diabetes onset induced by STZ were obtained by Zanoni et al. (2003), but with a resulting hyperglycemia higher than that observed in Group D and DS, probably due to the length of the trial period which was lower for Group D and DS (90 days).

The AA-supplementation of STZ-induced diabetic animals (Group DS) did not cause a significant decrease in the glucose concentration as also observed by Young et al. (1992).

The animals' body weight were not different $(P>0.05)$ among Group C $(295 \pm 15.81 \mathrm{~g})$, D $(283.3 \pm 11.24 \mathrm{~g})$, DS $(314 \pm 12.25 \mathrm{~g})$ and $C S(301.5 \pm 2.05 \mathrm{~g})$ at the beginning of the experiment (90 days). However, during the experiment, the animals from Group C and CS gained more $45 \%$ and $43 \%$ of weight, respectively, when compared to their initial weight. Animals from Group D and DS had a lower weight gain $(40 \%$ and $17 \%$, respectively). However, when compared to each other (Group DxDS), the average weight showed no significant difference $(P>0.05)$ at 180 days (end of the experiment).

Lower body weight gain by STZ-induced diabetic animals has been reported indicating that the gain intensity is related to the diabetes duration. Experimental period longer than 90 days cause less weight gain for diabetic animals (Zanoni et al. 2003, Clebis et al. 2004, Fregonesi et al. 2005, Silverio et al. 2008).

In higher vertebrates, the neuron organization in the myenteric plexus forming ganglia interconnected by nerve fibers between the muscle layer strata of the gastro-intestinal segments is well described in the literature (Gabella 1979, 1990, Molinari et al. 1994, Sant'Ana et al. 1997,
Furness 2000, Mari et al. 2007, Silva et al. 2008) and is not modified by diabetes (Zanoni et al. 1997, 2003, Silverio et al. 2008). Similarly, the plexus organization remained unchanged among the groups studied (C, CS, DS, and $D)$, not changing either with the diabetes onset and or by the AA-supplementation. The NADPH-dp neurons were distributed in a sparse way inside the ganglion in all groups, occupying the peripheral region of the ganglions as described by Miranda-Neto et al. (2001).

In the long run, it is known that the metabolic changes taking place in the diabetes are responsible for chronicdegenerative diseases complications that lead to vascular and nerve impairment (Crawford \& Cotran 1996, Squarzoni et al. 2007). Changes in the myenteric plexus are included in diabetic autonomic neuropathy (Araújo, 1996), whose etipatogeny has not been clarified yet (Cellek et al. 2003). The polyol pathway activity, among others, can be changed due to direct or indirect the intensification of the oxidative stress mediated by the hyperglycemia (Davison et al. 2002, Feldman 2003). In diabetes, the AA administration, an antioxidant substance and aldose reductase inhibitor [a fundamental enzyme to the polyol pathway] (Levine 1986, Will \& Byers 1996) is used in an attempt to minimize or prevent the deleterious consequences arising from diabetes. Thus, to verify the effects of AA-supplementation in STZ-induced diabetes in rats, the nitrergic neurons (NADPH-dp neurons) of the ileum myenteric plexus were measured and quantified.

There were no significant differences in the $13.33 \mathrm{~mm}^{2}$ ileum total area of animals from Group C, D, DS and CS ( $P>0.05$ ) among the densitiy of NADPH-dp neurons (Table 2) as well as the NOS-stained neurons observed by Wroz et al. (1997). A decrease in the number of myenteric neurons in STZ-induced diabetes in rats was observed in the stomach (Fregonesi et al. 2001, Clebis et al. 2004), in the duodenum (Romano et al. 1996, Buttow et al. 1997, Furlan et al. 1999), in the ileum (Zanoni et al. 2003, Alves et al. 2006), in the small intestine as a whole (Hernandes et al. 2000), in the cecum (Zanoni et al. 2007), in the proximal colon (Furlan et al. 2002). We can justify the controversial results for the NADPH-dp neurons in Group D, C, CS and DS when compared to other reports: the diabetes maintenance period as well as the neurochemical phenotype of the stained neurons was not similar. Enhanced changes in the neuronal density can be better observed when a generalized neuronal population is stained regardless of their neurochemical phenotype, as occurs, for example, with the use techniques such as the cuprolinic blue (Phillips et al. 2004), myosin V (Zanoni et al. 2003), NADH-diaphorase (Sant'Ana et al. 2001, Young et al. 1993, Molinari et al. 2002, Clebis et al. 2004, , Zanoni et al. 2007, Silva et al. 2008), methylene blue (Hernandes et al. 2000), among others, which stain the whole neuronal population, including the nitrergic neurons. When analyzing specific populations, such as NADPH-dp neurons, more specific results were obtained. Vinson et al. (1989) reported that not all types of myenteric neurons are affected 
simultaneously with the same intensity and extent, since the diabetes causes selective changes in the myenteric plexus (LePard 2005). The deleterious processes that lead to neuronal loss do so according to the differentiated neurochemical phenotype and neurons location. Nitrergic neurons are more resistant to the consequences arising from diabetes, as well as neurons in the duodenum are impaired earlier than colon neurons towards aboral-anal. In that order, the ileum precedes the colon; however, it is more resistant than the duodenum and jejunum.

On average, the neurons PC area of Group D $\left(289.8 \pm 5.5 \mathrm{ìm}^{2}\right)$ and $C\left(289.7 \pm 5.62 \mathrm{ìm}^{2}\right)$ were equivalent. However, the AA treatment significantly reduced $(P<0.05)$ the PC area of groups DS $\left(253.1 \pm 4,22 \mathrm{~mm}^{2}\right)$ and CS $\left(210.1 \pm 3.14 \mathrm{im}^{2}\right)$. The PC areas in Group DS and CS were $12.7 \%$ and $27.5 \%$ lower when compared to Group D and $C$, respectively (Table 2). A similar effect of the AA treatment on the PC area of diabetic animals is reported in the jejunum (Silverio et al. 2008) and in the ileum of rats that remained diabetic for 120 days (Zanoni et al. 2003).

There was an increase in the incidence of neurons with a PC area lower to $200 \mathrm{im}^{2}$ in Group DS and CS $(31 \%$ and $52 \%$, respectively) and a decrease in the incidence of neurons with a PC area exceeding $200 \mathrm{im}^{2}$ compared to the other groups ( $C=76 \%, D=81 \%, S D=69 \%$, and $C S=48 \%)$. Zanoni et al. (2003) and Silverio et al. (2008) have also found a decreased frequency of neurons in the PC area exceeding $200 \mathrm{im}^{2}$ and an increased incidence of neurons with a PC area lower less than to $200 \mathrm{im}^{2}$ in the ileum and jejunum of myenteric plexus of STZ-induced diabetic rats AA-treated, although with not with the same percentage.

The results suggest that, although the STZ-induced diabetes has not changed significantly the mean PC area when compared to Group $C$ and D, the AA supplementation had a protective effect in diabetic neurons (Group DS) as well as in the non-diabetic with a higher intensity in the last one (Group CS) since the PC area in those groups was lower. Zanoni et al. (2003) mentioned that the AA treatment may reduce the NOS expression. This, together with the inhibition of the aldose-reductase, results in the reduction of the NADPH-dp neurons PC area of the rat's ileum. As the treatment with $A A$ proved to be effective in reducing the $\mathrm{PC}$ area in the diabetic animals (DS) and non-diabetic (CS), with an even more pronounced decrease in the non-diabetic animals (CS), the results reinforce the AA neuroprotective function over the diabetes development, and more intensely, over aging. Also is suggestive that the intensity of diabetes effects on the $\mathrm{NADPH}-\mathrm{dp}$ neurons in the myenteric plexus is proportional to the diabetes time and the animal aging.

\section{CONCLUSIONS}

The results obtained in the stipulated conditions of this work allow the following conclusions regarding the myenteric plexus in the ileum of rats:

The intramural organization of the myenteric plexus and the number of NADPH-dp myenteric neurons in the ileum were neither altered by the AA supplementation nor by STZ-induced diabetes, suggesting a greater resistance of these neurons to the deleterious processes resulting from the STZ-induced diabetes;

The diabetes did not alter the mean PC area of NADPHdp myenteric neurons, but the AA supplementation worked as a neuroprotector preventing the increase in neurons $P C$ in the diabetic and non diabetic animals $A A$ supplemented;

The AA supplementation was responsible for a higher number of NADPH-dp neurons with a PC area lower to less than $200 \mathrm{im}^{2}$, with a more intense effect on the non diabetic rats, followed by the diabetic ones.

Acknowledgements.- The authors thank Dr. Haroldo Garcia de Faria for his help with the statistical analysis, and Unipar for financial support.

\section{REFERENCES}

Afzaal S., Singh M. \& Saleem I. 2002. Aetiopathogenesis and management of neuropathy. J. Assoc Physicians 50:707-711.

Alves A.M.P., Alves E.P.B, Fregonesi C.E.P.T., Defani M.A., Stabille S.R., Evangelista C.C.B., Santos C.A. \& Miranda-Neto M.H. 2006. Morphoquantitative aspects of nadh-diaphorase myenteric neurons in the ileum of diabetic rats treated with acetyl-I-carnitine. Anat. Histol. Embryol. 35:13-18.

Araújo A.E.J., Sant'Ana D.M.G., Molinari S.L. \& Miranda-Neto M.H. 2006. Quantitative study of the myenteric plexus of the descending colon of young rats subjected to intense protein deficiency. Int. J. Morphol. 24(3):591-596.

Araújo L. 1996. Neuropatia autonômica. Revta Bras. Neurol. 32(6):207209.

Block C.E.M., De Leeuw I.H., Pelckmans P.A., Callens D., Maday E. \& Van Gaal L.F. 2002. Delayed gastric emptying and gastric autoimmunity in type I diabetes. Diabetes Care 25(5):912-917.

Bornstein M., Costa M. \& Grider J.R. 2004. Enteric motor and interneuronal circuits controlling motility. Neurogastroenterol. Motil.16 (Suppl.1):34-38.

Brehmer A., Schrödl F., Neuhuber W., Tooyama I. \& Kimura H. 2004. Co-expression pattern of neuronal nitric oxide synthase and two veriants of choline acetyltransferase in myenteric neurons of porcine ileum. J. Chem. Neuroanat. 27:33-41.

Büttow N.C., Miranda-Neto M.H. \& Bazotte R.B. 1997. Morphological and quantitative study of the myenteric plexus of the duodenum of streptozotocin-induced diabetic rats. Arqs Gastroenterol. 34(1):35-42.

Cameron N.E. \& Cotter M.A. 1999. Effects of antioxidants on nerve and vascular dysfunction in experimental diabetes. Diabetes Res. Clin. Pract. 45(2):137-146.

Cameron N.E., Cotter M.A. \& Maxfield E.K. 1993. Anti-oxidant treatment prevents the development of peripheral nerve dysfunction in streptozotocin-diabetics rats. Diabetologia 36:299-304.

Cellek S., Foxwell N.A. \& Moncada S. 2003. Two phases of nitrergic neuropathy in streptozotocin-induced diabetic rats. Diabetes 52:235362.

Chandrasekharan B. \& Srinivasan S. 2007. Diabetes and the enteric nervous system. Neurogastroenterol. Motil. 19:951-960.

Clebis N.K., Stabille S.R., Seyfert C.E., Gagliardo K.M., Mari R.B., Guimarães J.P., Molinari S.L., Miranda-Neto M.H., Zanoni J.N., Rossi R.M., Janeiro V. \& Souza R.R. 2004. Avaliação quantitativa e morfométrica dos neurônios mioentéricos da região aglandular do estômago de ratos com diabetes mellitus induzido por estreptozootocina e suplementados com ácido ascórbico. Arqs Ciênc. Saúde Unipar 8(2):87-93. 
Crawford J.M. \& Cotran R.S 1996. Pâncreas, p.806-832. In: Cotran R.S., Kumar V., Robbins S.L. \& Schoen F.J. (Eds), Robbins' Patologia Estrutural e Functional. 5th ed. Guanabara Koogan, Rio de Janeiro.

Cunningham J.J. 1998. The glucose/insulin system and vitamin C: Implications in insulin-dependent diabetes mellitus. J. Am. Coll. Nutr. 17(2):105-108.

Davison G.W., George L., Jackson S.K., Young I.S., Davies B., Bailey D.M., Peters J.R. \& Ashton T. 2002. Exercise, free radicals, and lipid peroxidation in type I diabetes mellitus. Free Radical Biol.33:1543-1551.

Diani A.R., Grogan D.M., Yates M.E., Risinger D.L. \& Gerristsen G.C. 1979. Radiologic abnormalities and autonomic neuropathology in the digestive tract of the ketonuric diabetic Chinese hamster. Diabetologia 17:33-40.

Feldman E.L. 2003. Oxidative stress and diabetic neuropathy: A new understanding of an old problem. J. Clin. Invest. 111:431-433.

Fontes R.B.V., Froes L.B., Omar E.D. \& Liberti E.A. 2004. The myenteric plexus of the rat colon after fecal stream diversion: A morphoquantitative study. Autonomic Neurosci. Bas. Clin. 114:39-46.

Fregonesi C.E.P.T., Miranda-Neto M.H., Molinari S.L.\& Zanoni J.N. 2001. Quantitative study of the myenteric plexus of the stomach of rats with streptozotocin-induced diabetes. Arqs Neuropsiquiatr. 59(1):50-53.

Fregonesi C.E.P.T., Molinari S.L., Alves A.M.P., Defani M.A. \& Neto M.H.M. 2005. Morphoquantitative aspects of the nadph-diaphorase positive myenteric neurons from the stomach of diabetic rats. Arqs Ciênc. Saúde Unipar 9(3):8155-159.

Furlan M.M.D.P., Miranda-Neto M.H., Sant'Ana D.M.G. \& Molinari S.L. 1999. Number and size of myenteric neurons of the duodenum of adult rats with acute diabetes. Arqs Neuropsiquiatr. 57(3B):740-745.

Furlan M.M.D.P., Molinari S.L. \& Miranda-Neto M.H. 2002. Morphoquantitative effects os acute diabetes on the myenteric neurons of the proximal colon of adult rats. Arqs Neuro-Psiquiatr. 60(3A):576581.

Furness J.B. 2000. Types of neurons in the enteric nervous system. J. Auton. Nerv. Syst. 81:87-96.

Gabella G. 1979. Innervation of gastrointestinal tract. Int. Rev. Cytol. 59:129-191.

Gabella G. 1990. On plasticity of form and structure of enteric ganglia. J. Auton. Nerv. Syst. 30:559-566.

Giuliano D., Ceriello A. \& Paolisso G. 1996. Oxidative stress and diabetic vascular complications. Diabetes Care 19:257-267.

Hernandes L., Bazotte R.B., Gama P. \& Miranda-Neto M.H. 2000. Streptozotocin-induced diabetes duration is important to determine changes in the number and basophily of myenteric neurons. Arqs Neuorpsiquiatr. 58(3B):1035-1039.

Junod A., Lambert A.E., Stauffacher W. \& Renold A.E. 1969. Diabetogenic action of streptozotocin:relationship of dose to metabolic response. J. Clin. Invest. 48:2129-2139.

Kurjak M., Fritsch R., Saur D., Schusdziarra V. \& Allescher H.D. 2001. Functional coupling between nitric oxide synthesis and VIP release within enteric nerve terminals of the rat: envolvement of protein kinase $G$ and phosphodiesterase 5. J. Physiol. 534:827-836.

Lee A.Y.W. \& Chung S.S.M. 1999. Contribuitions of polyol pathway to oxidative stress in diabetic cataract. FASEB Journal 13:23-30

LePard K.J. 2005. Choline acetyltransferase and inducible nitric oxide synthase are increasef in myenteric plexus of diabetic guinea pig. Auton. Neurosci. Bas. Clin. 118:12-24.

Levine M. 1986. New concepts in the biology and biochemistry of ascorbic acid. New Engl. J. Med. 314:892-902.

Mari R.B., Molinari S.L., Clebis N.K. \& Stabille S.R. 2007. Morphoquantitative study of nadh-diaphorase positive myenteric neurons of the ileum of rats of Holtzman lineage (Rattus norvegicus). Acta Sci. Biol. 29(3):239-245.
Miranda-Neto M.H., Molinari S.L., Natali M.R.M. \& Sant'Ana D.M.G. 2001. Regional differences in the number and type of myenteric neurons of the ileum of rats. Arqs Neuropsiquiatr. 59(1):54-59.

Molinari S.L., Fernandes C.A., Oliveira L.R., Sant'Ana D.M.G. \& MirandaNeto M.H. 2002. Nadh-diaphorase positive myenteric neurons of the aglandular region of the stomach of rats (Rattus norvegicus) subjected to desnutrition. Revta Chil. Anat. 20(1):19-23.

Molinari S.L., Miranda-Neto M.H., Pereira M.A.S., Souza R.R. 1994. Estudo morfológico do plexo mioentérico do estômago glandular do pato (Anas sp.). Revta Unimar 16(2):419-426.

Obrosova I.G., Van Huysen C., Fathallah L., Cao X., Greene D.A. \& Stevens M.J. 2002. An aldose reductase inhibitor reverses early diabetes-induced changes in peripherical nerve function, metabolism and antioxidative defense. Fed. Am. Soc. Exp. Biol. J. 16:123-25.

Parthiban A., Vijayalingam S., Shanmugasundaram K.R. \& Mohan R. 1995. Oxidative stress and the development of diabetic complicationsantioxidants and lipid peroxidation in erythrocytes and cell membrane. Cell Biol. Int. 19:987-993

Phillips R.J., Hargrave S.L., Rhodes B.S., Zopf D.A. \& Powley T.L. 2004. Quantification of neurons in the myenteric plexus: An evaluation of putative pan-neuronal markers. J. Neurosci. Methods 133:99-107.

Rigo A. \& Guterres S.S. 2002. O potencial antioxidante de vegetais no combate ao envelhecimento cutâneo. Infarma 14:69-73.

Romano B.E., Miranda-Neto M.H. \& Cardoso R.C.S. 1996. Preliminary investigation about the effects of streptozotocin-induced chronic diabetes on the nerve cell number and size of myenteric ganglia in rat colon. Revta Chil. Anat. 14(2):139-145.

Sant'Ana D.M.G., Miranda-Neto M.H., Molinari S.L. \& Sant'Ana M.A. 1997. Neurons number in the myenteric plexos of the ascending colon of rats. A comparative study using two staining techniques. Arqs Neuropsiquiatr. 55(3a):460-465.

Sant'Ana D.M.G., Molinari S.L. \& Miranda-Neto M.H. 2001. Effects of protein and vitamin $B$ deficiency on blood parameters and myenteric neurons of the colon of rats. Arqs Neuropsiquiatr. 59(3A):493-498.

Santer R.M. 1994. Survival of the population of nadph-diaphorase stained myenteric neurons in the small intestine of aged rats. J. Auton. Nerv. System 49:115-121.

Scherer-Singler U., Vincent S.R., Kimura H. \& McGeer E.G. 1983. Demonstration of a unique population of neurons with nadphdiaphorase histochemistry. J. Neurosci. Methods 9:229-234.

Silva E.A., Natali M.R.M. \& Prado I.M.M. 2008. The number and profile of reactive nadh-d and nadph-d neurons of myenteric plexus of sixmonth-old rats are different in the cecum portions. Pesq. Vet. Bras. 28(5):291-248.

Silverio S.M., Mari R.B., Clebis N.K., Scoz J.R., Germano R.M., Agreste F., Bombonato P.P. \& Stabille S.R. 2008. Assessment of nadphdiaphorase stained myenteric neurons of the jejunum of diabetic rats supplemented with ascorbic acid. Pesq. Vet. Bras. 28(2):95-102.

Spangéus A., Suhr O. \& El-Salhy M. 2000. Diabetic state affects the innervation of gut in an animal model of human type I diabetes. Histol. Histopathol. 15:739-744.

Squarzoni R., Morales M.S.A., Safatle A.M.V. \& Barros P.S.M. 2007. Avaliação ultra-sonográfica do segmento posterior de olhos de cães diabéticos e não diabéticos portadores de catarata. Pesq. Vet. Bras. 27(11):455-461.

Surendran S. \& Kondapaka S.B. 2005. Altered expression of neuronal nitric oxide symthase in the duodenum longitudinal muscle-myenteric plexus of obesity induced diabetes mouse: Implications on enteric neurodegeneration. Biochem. Biophys. Res. Commun. 338:919922.

Vinson J.A., Staretz M.E., Bose P., Kassm H.M. \& Basalyga S.B. 1989. In vitro and in vivo reduction of erythrocyte sorbitol by ascorbic acid. Diabetes 38:1036-1041. 
Watkins C.C., Sawa A., Jaffrey S., Blaekshaw S., Barrow R.K., Snyder S.H. \& Ferris C.D. 2000. Insulin restores neuronal nitric oxide synthase expression and function that is lost in diabetic gastropathy. J. Clin. Invest. 106(3):373-384.

Will J.C. \& Byers T. 1996. Does diabetes mellitus increase the requirement for vitamin C? Nutr. Rev. 54:193-202.

Wrzos H.F., Cruz A., Polavarapu R., Shearesr D. \& Ouyang A. 1997. Nitric oxide synthase (NOS) expression in the myenteric plexus of streptozotocin-diabetic rats. Digest. Dis. Sci. 42:2106-2110.

Young H.M., Furness J.B., Sewell P., Burcher E.F. \& Kandiah C.J. 1993. Total numbers of neurons in myenteric ganglia of the guinea-pig small intestine. Cell Tissue Res. 272:197-200.

Young I.S., Torney J.J. \& Trimble E.R. 1992. The effect of ascorbate supplementation on oxidative stress in the streptozotocin diabetic rat. Free Rad. Biol. 13:41-46.

Zanoni J.N., Buttow N.C., Bazotte R.B. \& Miranda-Neto M.H. 2003. Evaluation of the population of nadph-diaphorase-stained and myosin$\mathrm{V}$ myenteric neurons in the ileum of chronically streptozotocin-diabetic rats treated with ascorbic acid. Auton. Neurosci. Basic Clin. 104:32-38.

Zanoni J.N., Miranda-Neto M.H., Bazotte R.B. \& Souza R.R. 1997. Morphological and quantitative analysis of the neurons of the myenteric plexus of the cecum of streptozotocin-induced diabetic rats. Arqs Neuropsiquiatr. 55(4):696-702.

Zanoni J.N., Pereira R.V.F. \& Freitas P. 2007. Effect of the ascorbic acid treatment on the nadhd-positive myenteric neurons of diabetic rats proximal colon. Braz. Arch. Biol. Technol. 50(1):31-38. 